\title{
The Experimental Study of The Effect of Air Preheating in MSW Pellet Multi-Stage Downdraft Gasifier
}

\author{
Depi Rustam Ependi, Arif Rahman Saleh, and Bambang Sudarmanta
}

\begin{abstract}
High municipal solid waste generation in Indonesia can be used to substitute fossil energy. MSW is converted into pellet form to uniform moisture content. This study aimed to improve the performance of gasified downdraft gasifier processes by heating air inlets in pyrolysis, oxidation, and reduction zones. Variations of air temperature inlet in these zones are $80^{\circ} \mathrm{C}, 110{ }^{\circ} \mathrm{C}, 150{ }^{\circ} \mathrm{C}$, and $210^{\circ} \mathrm{C}$. The results of this study obtained the highest air temperature at $210{ }^{\circ} \mathrm{C}$ for $969^{\circ} \mathrm{C}$. The syn-gas compositions ( $\mathrm{CO}$ and $\mathrm{H}_{2}$ ) at an increase in temperature of $80-210{ }^{\circ} \mathrm{C}$ increased from $21.4 \%, 9.99 \%$, and $1.77 \%$ to $22.79 \%, 10.28 \%$, and $1,79 \%$ respectively. Cold gas efficiency increased by $5.13 \%$ and the lowest tar level was 34.39 $\mathrm{mg} / \mathrm{Nm}^{3}$. Based on the result of research, preheated air can improve the efficiency of gasification and reduce tar content in the syngas..
\end{abstract}

Keywords_-MSW pellet, gasification, preheated air, multi-stage

\section{INTRODUCTION}

$\mathrm{M}$ SW (Municipal Solid Waste) is an urban solid waste that we often find every day. At present, MSW utilisation is still very low. One way to convert MSW into energy is gasification technology. To uniform the moisture content in MSW, the MSW is converted into a pellet first. Gasification is a thermochemical process that converts biomass into useful gas by a partial oxidation process using air, oxygen or steam [1]. In general, the gasification process is divided into four stages: (1) drying process (endothermic stage), (2) pyrolysis (endothermic stage), (3) partial oxidation (exothermic stage) and, (4) reduction process (endothermic stage). The gasification product is called synthetic gas (syngas) containing $\mathrm{CO}, \mathrm{H}_{2}$, and $\mathrm{CH} 4$ as a combustible gas. In this research, the gasification process using downdraft type gasifier. Downdraft gasifier has several advantages, namely high carbon conversion rate, low tar production, and simple reactor design [2].

Several studies have been conducted to improve the efficiency of gasification and reduce tar levels in the syngas. One of them is by heating the air used as an internal gasification agent (heated in the gasifier) and externally (heated before entering the gasifier). Bhattacharya and Dutta [3] preheat air at an optimum temperature of $210{ }^{\circ} \mathrm{C}$, the resulting oxidation zone temperature of $1000{ }^{\circ} \mathrm{C}$, and at this temperature, the tar level in syngas can be reduced to $10 \mathrm{mg} / \mathrm{Nm}^{3}$. In addition, according to a study by Guanggul [4], heating of air prior to entering the oxidation zone to $200{ }^{\circ} \mathrm{C}$ temperature can increase the quality of syngas produced by increasing volumetric percentage $\mathrm{H} 2$ from $8.47 \%$ to $10.53 \%, \mathrm{CO}$ from $22.87 \%$ to $24.94 \%, \mathrm{CH} 4$ from $2.02 \%$ to $2.03 \%$, and $\mathrm{HHV}$ from $4.66 \mathrm{MJ} / \mathrm{Nm}^{3}$ to $5.31 \mathrm{MJ} / \mathrm{Nm}^{3}$. Sudarmanta performs gasification characterisation, the results of his research show the effect of heating the inlet air of the oxidation zone with the external heating to the temperature distribution at the reactor, in particular, the oxidation zone [5]. The study showed that air heating

Depi Rustam Ependi, Arif Rahman Saleh, and Bambang Sudarmanta are with Department of Mechanical Engineering, Institut Teknologi Sepuluh Nopember, Surabaya, 60111, Indonesia. E-mail: tgh_hary@yahoo.com. from $30^{\circ} \mathrm{C}$ to $70{ }^{\circ} \mathrm{C}$ increased the temperature of the oxidation zone from $710^{\circ} \mathrm{C}$ to $800^{\circ} \mathrm{C}$, which by increasing the temperature reduces tar levels and increases the quality of syngas (increases the syngas energy from $41,311 \mathrm{~kJ}$ to $44,001 \mathrm{~kJ})$. Then on downdraft reactor which is currently in the laboratory of Combustion and Energy Systems has been conducted by Akbar [6] concerning temperature distribution at reactor zones with the existence of internal air heater in the form of air pipe belt wrapped around the oxidation zone. From the research obtained temperature in the oxidation zone of $800{ }^{\circ} \mathrm{C}$ and LHV of $3.699 \mathrm{~kJ} / \mathrm{kg}$. Based on these explanations, the addition of an external air heater (preheated water) can increase the desired gasification temperature. However, a study conducted by Sudarmanta [5] and Akbar [6] only heated the air up to $70^{\circ} \mathrm{C}$ while the optimum temperature of warming reached $210{ }^{\circ} \mathrm{C}$. Therefore, this study will add an external air heater from $80{ }^{\circ} \mathrm{C}$ up to $210{ }^{\circ} \mathrm{C}$ before the air enters the internal heating to be supplied into the downdraft reactor oxidation zone with MSW pellet feedstock. So it is expected to increase the composition of combustible syngas $\left(\mathrm{CO}, \mathrm{H}_{2}\right.$, and $\left.\mathrm{CH}_{4}\right)$ and reduce tar content.

\section{METHOD}

The raw materials used in this research are MSW pellets $15 \mathrm{~cm}$ in length and $8 \mathrm{~mm}$ in diameter. MSW pellet composition comprises $60 \%$ organic matter and $40 \%$ inorganic [7]. Then, in this study, downdraft type reactors with multilevel air inputs in pyrolysis, oxidation and reduction zones [8][9], and [10] were modified by adding external heaters to the inlet air. This external heater comes from an open coil heater that is installed in the air input pipe. The addition of external heaters is done because internal heaters in the pyrolysis, oxidation, and reduction zones are not able to increase air temperature to $210{ }^{\circ} \mathrm{C}$. Experiments are designed with schemes like Figure. 1.

Experiments were conducted with five variations of air temperature in pyrolysis, oxidation and reduction zones, $80{ }^{\circ} \mathrm{C}, 110{ }^{\circ} \mathrm{C}, 150{ }^{\circ} \mathrm{C}, 180{ }^{\circ} \mathrm{C}$, and $210{ }^{\circ} \mathrm{C}$. Air ratio and equivalence ratio are kept constant at 1:8:1 and 0.4 respectively. Measurement of temperature distribution using thermocouples mounted along the reactor ( $\mathrm{T} 1$ to 


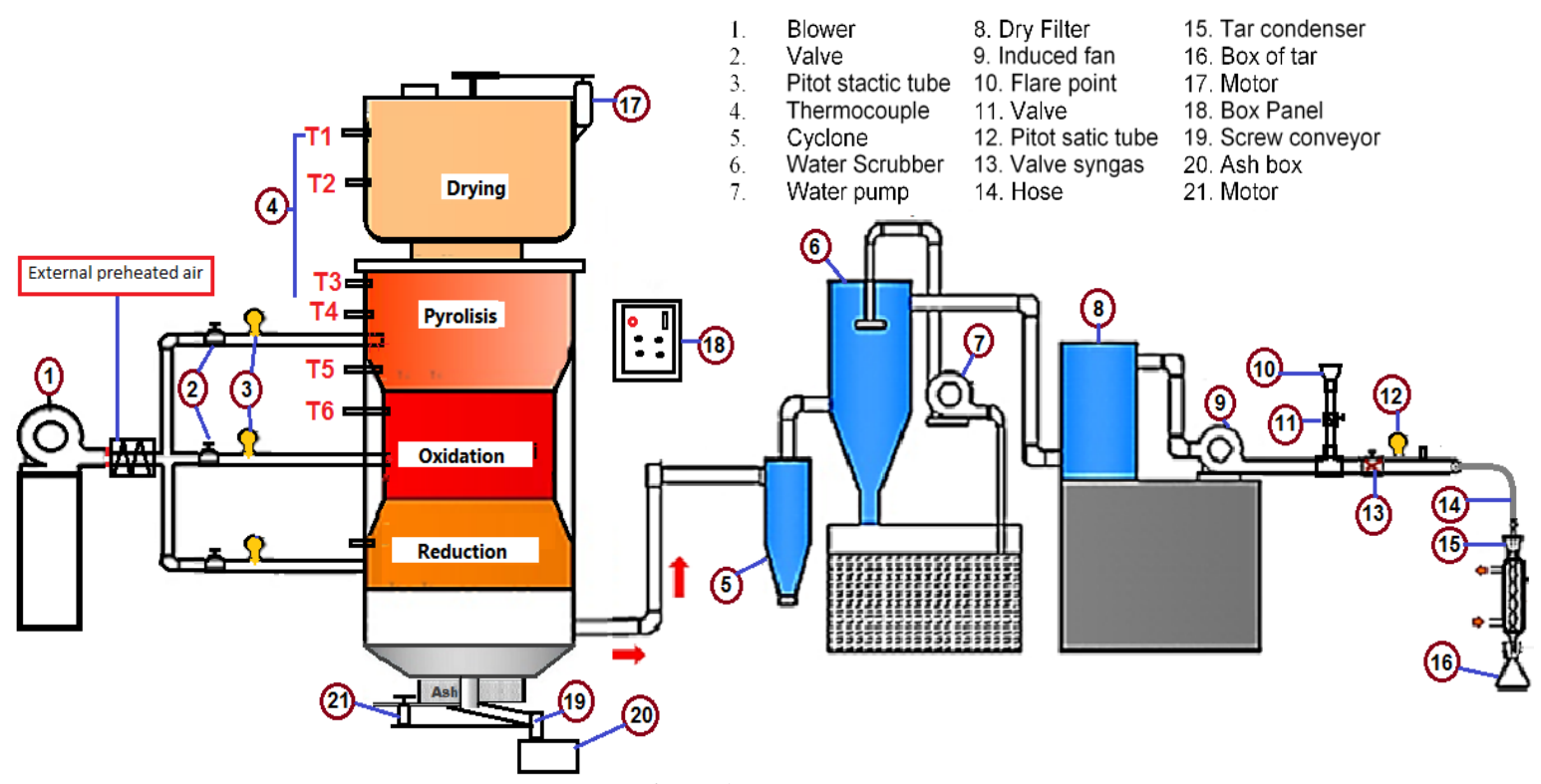

Figure 1. Experimental setup.

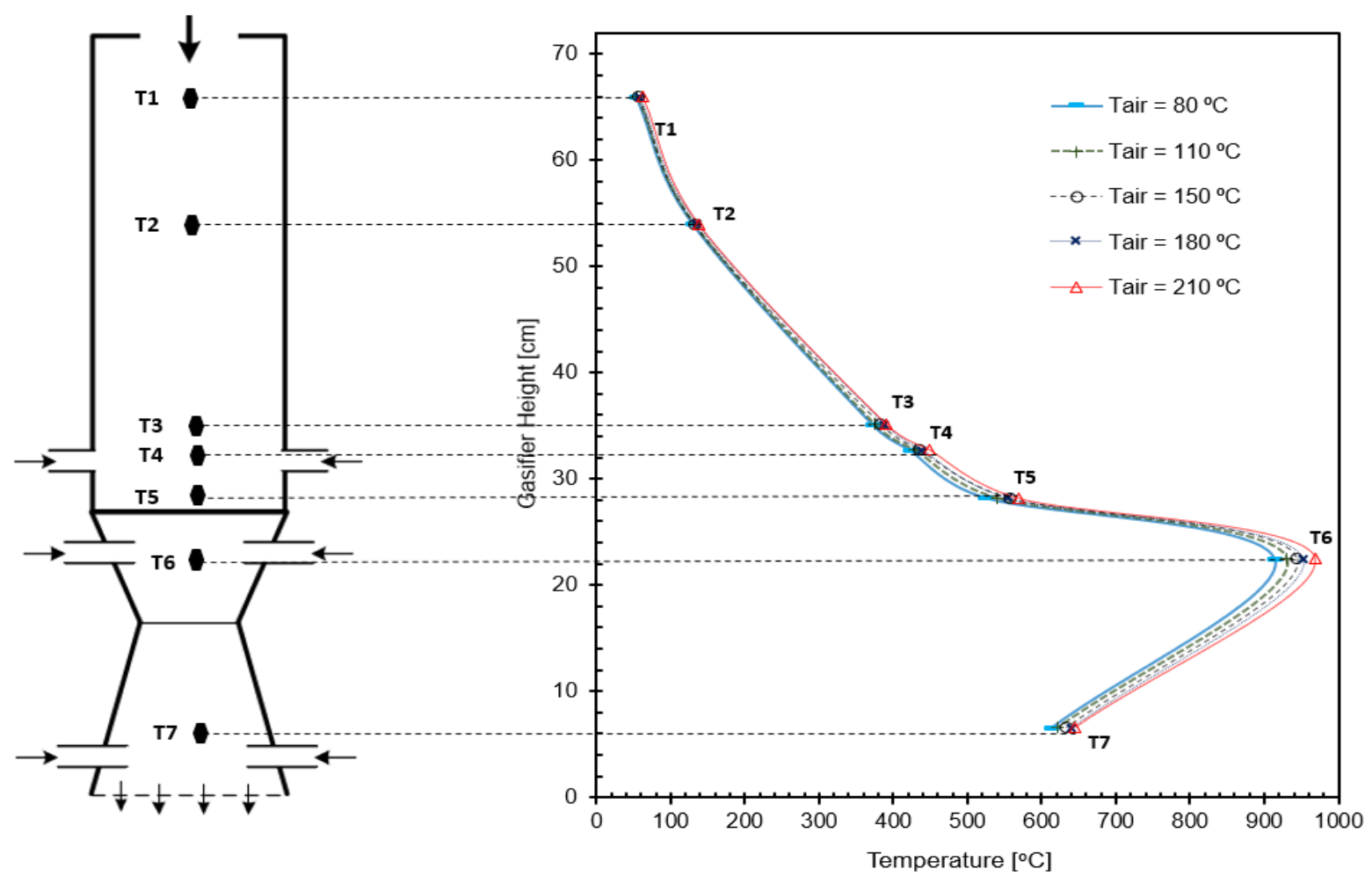

Figure 2. Temperature profile of gasification process.

T7) in Figure. 1. Then the composition of combustible syngas was measured using gas chromatography, and samples were taken at syngas output (shown with no 15 in Figure. 1). The content of tar in the syngas is measured using a tar condenser.

\section{RESULTS AND DISCUSSION}

The MSW pellets have characteristics as shown in Table. 1. These characteristics are used to calculate the equivalence ratio and the input energy of the gasification process. Next. The performance of a gasifier in generating combustible gas can be observed from several parameters, including temperature distribution throughout the reactor (drying zone, pyrolysis zone, oxidation zone and reduction zone), combustible syngas composition, cold gas efficiency, and tar content. These parameters were reviewed with variations of multi-stage inlet air temperature and analysed its effect.

\section{A. Temperature Distribution along Gasifier}

Figure 2 shows thermocouples (T1) and (T2) at a temperature interval of 50 to $150{ }^{\circ} \mathrm{C}$. The interval shows that at an altitude of $90-120 \mathrm{~cm}$ there has been evaporation of water content. Then, $\mathrm{T} 1$ and $\mathrm{T} 2$ are located in the drying zone, where all the water content in MSW has run out. Also, the temperature at the oxidation zone (T6) has increased significantly along with the increase in air temperature. This is due to the high air temperature makes the reaction of partial oxidation, and char combustion in the oxidation zone becomes more reactive. Also, heating the air can increase the enthalpy of oxygen as a reactant, thus making the energy difference of products and reactants grow larger. The 
TABLE 1.

BASIC CHARACTERISTICS OF THE PELLET MSW

\begin{tabular}{ll}
\hline \hline Proximate analysis (\% wt) & \\
\hline Moisture content & 10.23 \\
Ash content & 5.73 \\
Volatile matter & 70.93 \\
Fixed carbon & 13.11 \\
Ultimate analysis (\% wt) & \\
C & 50.34 \\
H & 4.91 \\
O & 38.83 \\
N & 0.13 \\
S & 0.06 \\
HHV & $16.88 \mathrm{MJ} / \mathrm{kg}$ \\
LHV & $15.69 \mathrm{MJ} / \mathrm{kg}$ \\
\hline \hline
\end{tabular}

highest oxidation temperature was obtained at the variation of air temperature $210{ }^{\circ} \mathrm{C}$ equal to $969{ }^{\circ} \mathrm{C}$. Temperature increases also occur in $\mathrm{T} 5$ and $\mathrm{T} 7$ which are pyrolysis zone temperatures and reduction zones. Two factors cause temperature increases in pyrolysis zones and reduction zones. First, the heating of the air makes the oxidative reaction of pyrolysis, and the heterogeneous oxidation reaction in the reduction zone becomes more reactive. Second, an increase in the temperature of the oxidation zone (exothermic) causes heat transfer to the pyrolysis zone and the higher the reduction. Highest pyrolysis and reduction temperatures were obtained at variations of air temperature $210{ }^{\circ} \mathrm{C}$ for $569{ }^{\circ} \mathrm{C}$ and $644^{\circ} \mathrm{C}$ respectively.

The gasifier temperature increases when the air temperature (gasifying agent) is heated. The highest temperature increase occurs at the T6 thermocouple point located in the oxidation zone. The increase in temperature on $\mathrm{T} 6$ when the air temperature is increased to $210{ }^{\circ} \mathrm{C}$, is $55^{\circ} \mathrm{C}$. Besides that, the increase in gasifier temperature also occurs at the thermocouple points $\mathrm{T} 3$, $\mathrm{T} 4, \mathrm{~T} 5$, and $\mathrm{T} 7$. When the air temperature is heated to $210{ }^{\circ} \mathrm{C}$, the increase in temperature at the thermocouple points T3, T4, T5, and T7 is $19,26,45$, and $49{ }^{\circ} \mathrm{C}$ respectively. Whereas at the thermocouple point $\mathrm{T} 1$ and $\mathrm{T} 2$ the gasifier temperature increase due to air heating is not significant. This is because the thermocouple points $\mathrm{T} 1$ and $\mathrm{T} 2$ are located far from the heat source (oxidation zone) and also there is no air entering this zone.

The increase in gasifier temperature is caused by an increase in enthalpies of air as a reactant which causes changes in the enthalpies formation to become large. That makes the reaction speed increase following the equation in Figure 2.7. Then, in this study the ratio of air into the gasifier is 1: $8: 1$, which means that $10 \%$ of the air enters the pyrolysis zone, $80 \%$ to the oxidation zone, and $10 \%$ to the reduction zone. This comparison causes a difference in the increase in gasifier temperature. The high percentage of air intake results in a very significant effect of heating the air in the oxidation zone.

The effects of rising temperatures on pyrolysis, oxidation, and reduction zones are the increasing of combustible gas compositions, especially $\mathrm{CO}$ and $\mathrm{H}_{2}$. Then, increasing the temperature of these zones can also reduce the tar content in the syngas.

\section{B. Syngas Composition}

Figure. 3 represents the volumetric percentage value of the $\mathrm{CO}, \mathrm{H}_{2}, \mathrm{CH}_{4}$, and $\mathrm{O}_{2}$ compounds present in the syngas at each variation of air temperature. At $59-210{ }^{\circ} \mathrm{C}$ increase in air temperature, the volumetric percentage of

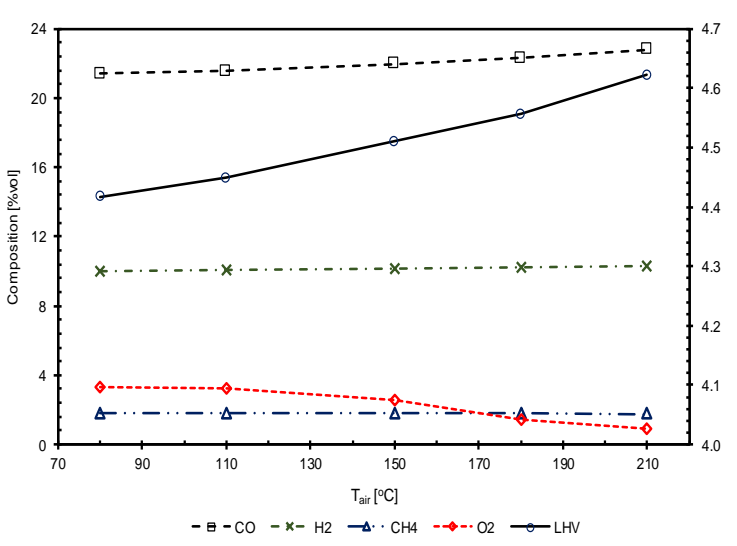

Figure 3. Composition and LHV of syngas

$\mathrm{CO}$ and $\mathrm{H}_{2}$ compounds increased by $1.7 \%$ and $0.31 \%$. Increased volumetric $\mathrm{CO}$ percentage is caused by increasing rate of oxidation reaction in three gasification zones (pyrolysis, oxidation, and reduction). The relation between the reaction rate and the reaction temperature is shown in Equations (1) [1].

$$
k=A_{0} \exp \left(-\frac{E}{R T}\right)
$$

$\mathrm{k}$ is the constant of the reaction rate, $\mathrm{A}_{0}$ is the pre exponential constant, $\mathrm{R}$ is the universal gas constant, $\mathrm{E}$ is the activation energy, and $\mathrm{T}$ is the reaction temperature.

Then the volumetric percentage of $\mathrm{CH}_{4}$ did not increase significantly when it was raised at $59-200{ }^{\circ} \mathrm{C}$. This is because the reaction rate of methanation in the reduction zone $\left(\mathrm{C}+2 \mathrm{H}_{2} \rightarrow \mathrm{CH}_{4}\right)$ occurs very slowly [3]. So the inlet air temperature is not so influential on the formation of $\mathrm{CH}_{4}$

Increasing the $\mathrm{CO}$ and $\mathrm{H}_{2}$ composition in Figure. 3 along with increasing air temperature, followed by decreasing $\mathrm{O}_{2}$ composition which is non-flammable syngas. The $\mathrm{O}_{2}$ composition of syngas is oxygen derived from the inlet air of an unreacted oxidation zone. Therefore, the decrease in the $\mathrm{O}_{2}$ composition is due to increased air temperature inlet to the gasification zone. Then, according to Basu [3], In a char combustion reaction in the oxidation zone there is a partition coefficient $(\beta)$ which has a relationship with the surface temperature of the charcoal (Toxidation) with Equation (2) [11] as follows:

$$
\beta=\frac{[\mathrm{CO}]}{\left[\mathrm{CO}_{2}\right]}=2400 e^{-\left(\frac{6234}{T}\right)}
$$

$\mathrm{T}$ is the surface temperature of the charcoal $(\mathrm{K})$, which in this study is a measured temperature at T6.

Increased compositions of combustible syngas (CO and $\mathrm{H}_{2}$ ) make the syncopated lower calorific value (LHV) syngas increased. This indicates that warming of air temperature can increase the energy of gasification process output. Then also the increased energy output of MSW pellet gasification makes the gasification process more efficient.

\section{Cold Gas Efficiency}

The performance parameter of the next gasification process is cold gas efficiency. Figure. 4(a) shows that with an increase in air temperature of $59-210{ }^{\circ} \mathrm{C}$ it can increase the cold gas efficiency by $6.07 \%$ with a relatively linear increase. The increase is due to the increase of LHV in the syngas. The volumic rate of 


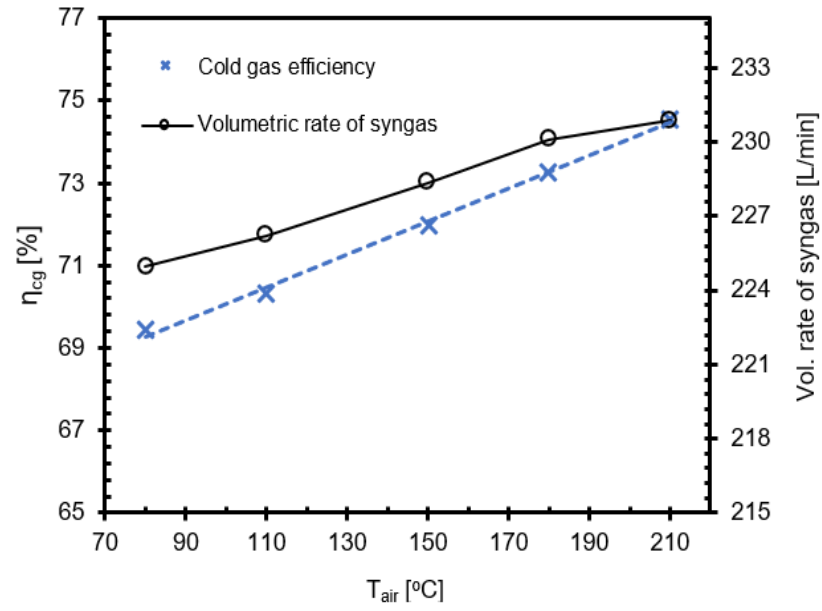

(a)

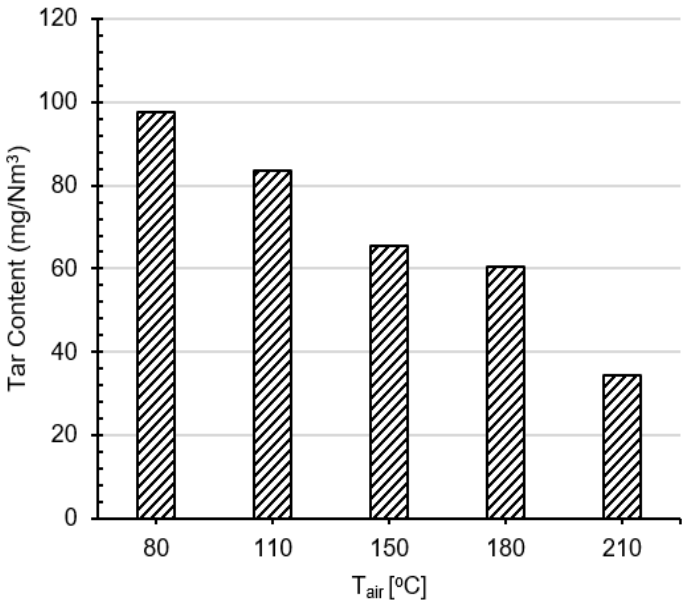

(b)

Figure 4. (a) Volumetric rate of syngas and cold gas efficiency. (b) Tar content in syngas.

syngas also influences it. Can be seen in Figure. 4(a), when the air temperature is increased, the volumetric rate of syngas also increases. This indicates that with the increase in air temperature can maximise the reaction between biomass and air, which is characterised by an increase in the volumetric rate of syngas

Figure. 4(a) also shows the trend value of cold gas efficiency on heating air temperature 80-210 ${ }^{\circ} \mathrm{C}$ not found peak value or curve of upward trend becomes a downward trend. This indicates, the value of cold gas efficiency at air temperature exceeding $200{ }^{\circ} \mathrm{C}$ still possible to increase to a specific temperature.

\section{Tar Content}

The use of allowed syngas for diesel engines should have a tar content below $100 \mathrm{mg} / \mathrm{Nm}^{3}$ [12][13], and [14]. Therefore, the output parameter of the gasification process that needs to be analysed is the tar content in the syngas. Figure. 4(b) shows a graph of the effect of increasing air temperature on tar content in the syngas.

In Figure. 4(b), the tar content decreased in $80-210{ }^{\circ} \mathrm{C}$ air temperature variations by $70 \%$. The addition of a heater to increase the temperature of the inlet air of the oxidation zone affects the temperature of the gasifier thus causing the reduction of the tar content in syngas by a process called thermal cracking. Thermal cracking is a process used to reduce tar content by increasing temperature.

The content of tar in the syngas is strongly influenced by the temperature of the gasifier. The higher the temperature value of the gasifier, the tar content in syngas will be smaller. The gasifier temperature in this study is above $900{ }^{\circ} \mathrm{C}$, so the type of tar that dominates is the tertiary and secondary tar [1]. Tertiary tars have lower molecular mass than secondary tars, and primary tars, the tar content present in syngas at higher gasifier temperatures will have a lower tar content.

\section{CONCLUSION}

Based on the results obtained from the research conducted, it can be concluded as follows:

1. Increase inlet air temperature of pyrolysis, oxidation, and reduction zones, from $80{ }^{\circ} \mathrm{C}$ to 210 ${ }^{\circ} \mathrm{C}$ increases the temperature of the oxidation zone from $914{ }^{\circ} \mathrm{C}$ to $969^{\circ} \mathrm{C}$, the pyrolysis temperature from 524 to $569{ }^{\circ} \mathrm{C}$, and the reduction zone temperature from $595{ }^{\circ} \mathrm{C}$ to $644^{\circ} \mathrm{C}$

2. The gasification process in MSW pellets with the addition of external heaters can increase the volumetric percentage of combustible syngas ( $\mathrm{CO}$ and $\mathrm{H}_{2}$ ) from $21.4 \%$ and $9.99 \%$ to $22.79 \%$, and $10.28 \%$ respectively

3. Cold gas efficiency increases linearly with increasing temperature of the inlet air of the oxidation zone. Increased air temperature (80-210 ${ }^{\circ} \mathrm{C}$ ) due to the addition of external heaters to make cold gas efficiency increased by $5.13 \%$.

4. The tar content in the lowest syngas is worth 34.39 $\mathrm{mg} / \mathrm{Nm}^{3}$, i.e. at $210^{\circ} \mathrm{C}$ inlet air temperature.

\section{ACKNOWLEDGMENT}

The authors would like to thank Lembaga Penelitian dan Pengabdian Masyarakat (LPPM) Institut Teknologi Sepuluh Nopember for providing the research fund for this work.

\section{REFERENCES}

[1] P. Basu, Biomass Gasification, Pyrolysis, and Torrefaction. India: Academic Press, 2013.

[2] A. Molino, S. Chianese, and D. Musmarra, "Biomass Gasification Technology: The State of The Art Overview," J. Energy Chem., vol. 25, pp. 10-25, 2016.

[3] Bhattacharya and A. Dutta, "Two-Stage Gasification Of Wood With Preheated Air Supply: A Promising Technique For Producing Gas Of Low Tar Content," Bioresour. Technol., vol. 126, pp. 224-232, 2012.

[4] F. M. Guanggul, S. A. Sulaiman, and A. Ramli, "Gasifier Selection, Design and Gasification of Oil Palm Fronds with Preheated and Unheated Gasifying Air," Bioresour. Technol., vol. 126, pp. 224-232, 2012.

[5] B. Sudarmanta, D. Murtadji, and D. Wulansari, "Karakterisasi Biomassa Sekam Padi Menggunakan Reaktor Downdraft dengan Dua Tingkat Laluan Udara," Surabaya, 2009.

[6] F. Akbar and B. Sudarmanta, "Studi Eksperimental Pengaruh Air Fuel Ratio Proses Gasifikasi Briket Municipal Solid Waste Terhadap Unjuk Kerja Gasifier Tipe Downdraft," Surabaya, 2016.

[7] Indarto, "Karakterisasi unjuk Kerja Mesin diesel generator set sistem dual fuel solar dan biogas dengan penambahan fan Udara sebagai penyuplai Udara," Surabaya, 2016.

[8] Bhattacharya and et al, "A study on multi-stage hybrid gasifier engine system," Biomass and Bioenergy, vol. 21, pp. 445-460, 2011.

[9] B. Sudarmanta, A. Gafur, A. Saleh, R. Dwiyantoro, and Sampurno., "The effect of two stage gasifying agent on 
biomass downdraft gasification to the gasifier performance," in AIP Conference Proceedings, 2018.

[10] A. Saleh and B. Sudarmanta, "Experimental investigation on multi-stage downdraft gasification: Influence of air ratio and equivalent ratio to the gasifier performance," in AIP Conference Proceedings, 2018.

[11] J. Arthur, "Reaction between carbon and oxygen," Trans Faraday Soc, vol. 47, pp. 164-178, 1951.

[12] M. Brown, G. Mudge, and B. K., "Evaluation of processes for removal of particulates, tars, and oil from biomass gasifier product gases," in Energy from Biomass and Wastes X, 1987.

[13] A. Bridgewater, "The Technical and Economic Feasibility of Biomass Gasification for Power Generation," Fuel, vol. 74 no. 5, pp. 631-653, 1995.

[14] H. Stassen, "UNDP/WB Small Scale Biomass Gasifier Monitoring Report," Netherlands, 1993. 